\title{
A comparison of advanced heat recovery power cycles in a combined cycle for large ships
}

\author{
Larsen, Ulrik; Sigthorsson, Oskar; Haglind, Fredrik
}

Published in:

Energy

Link to article, DOI:

10.1016/j.energy.2014.06.096

Publication date:

2014

Link back to DTU Orbit

Citation (APA):

Larsen, U., Sigthorsson, O., \& Haglind, F. (2014). A comparison of advanced heat recovery power cycles in a combined cycle for large ships. Energy, 74, 260-268. https://doi.org/10.1016/j.energy.2014.06.096

\section{General rights}

Copyright and moral rights for the publications made accessible in the public portal are retained by the authors and/or other copyright owners and it is a condition of accessing publications that users recognise and abide by the legal requirements associated with these rights.

- Users may download and print one copy of any publication from the public portal for the purpose of private study or research.

- You may not further distribute the material or use it for any profit-making activity or commercial gain

- You may freely distribute the URL identifying the publication in the public portal

If you believe that this document breaches copyright please contact us providing details, and we will remove access to the work immediately and investigate your claim 


\title{
A comparison of advanced heat recovery power cycles in a combined cycle for large ships
}

\author{
Ulrik Larsen*, Oskar Sigthorsson, Fredrik Haglind \\ Section of Thermal Energy, Department of Mechanical Engineering, Technical University of Denmark, \\ Building 403, Nils Koppels Allé, 2800 Kongens Lyngby, Denmark
}

\begin{abstract}
Strong motivation exists within the marine sector to reduce fuel expenses and to comply with ever stricter emission regulations. Heat recovery can address both of these issues. The organic Rankine cycle (ORC), the Kalina cycle and the steam Rankine cycle have received the majority of the focus in the literature. In the present work we compare these cycles in a combined cycle application with a large marine two-stroke diesel engine. We present an evaluation of the efficiency and the environmental impact, safety concerns and practical aspects of each of the cycles. A previously validated numerical engine model is combined with a turbocharger model and bottoming cycle models written in Matlab. Genetic algorithm optimisation results suggest that the Kalina cycle possess no significant advantages compared to the ORC or the steam cycle. While contributing to very high efficiencies, the organic working fluids possess high global warming potentials and hazard levels. It is concluded that the ORC has the greatest potential for increasing the fuel efficiency, and the combined cycle offers very high thermal efficiency. While being less efficient, the steam cycle has the advantages of being well proven, harmless to the environment as well as being less hazardous in comparison.
\end{abstract}

Keywords: Ship propulsion, Heat recovery, Organic Rankine cycle, Kalina cycle, Steam Rankine cycle

\section{Introduction}

The world seaborne trade has been growing in the last decades [1] and there is ever more motivation for reducing the pollution from large ships. Currently, international regulations on emissions of $\mathrm{CO} 2$ (and energy efficiency) and oxides of sulphur and nitrogen (SOx and NOx) are changing towards stricter limits [1]. An important focus area in the efforts to reduce these emissions is waste heat recovery (WHR) systems. WHR systems are designed to recover engine waste heat and produce mechanical or electric power and if coupled with a engine shaft motor, a reduction of the main engine load is possible.

Being among the most common types of vessels in the current world fleet, the case in focus in this study is a feeder class container ship which has a typical capacity of 2500 TEU (twenty foot equivalent units) containers and a length of 200 meter. Widely used in this class, and used as the case study here, is the MAN Diesel \& Turbo 7L70MC two-stroke low speed diesel engine with seven cylinders each with a bore of $70 \mathrm{~cm}$, and a maximum continuous rating of about $20 \mathrm{MW}$.

Waste heat recovery systems are not yet standard in this class of vessels although solutions are currently available, namely either a steam Rankine plant or alternatively an

\footnotetext{
*Principal corresponding author. Tel.: +4553250303

Email address: ulrik.larsen@chalmers.se (Ulrik Larsen)
}

exhaust gas power turbine. In the literature the most often mentioned alternatives to the steam cycle are the organic Rankine cycle (ORC) and the Kalina cycle. The ORC has been proposed for various applications of WHR including maritime ones for example by MAN Diesel \& Turbo [2] as a WHR solution for smaller engines. The Kalina cycle has in the literature $[3,4]$ been claimed to possess potential to achieve higher conversion efficiencies for WHR in general, compared to both ORC and steam Rankine cycles. Controversy exists however, and modelling efforts [5] have showed that the performance of ORC and Kalina may, at best, may be similar for marine application. For this reason it is the goal of the present study to compare the three mentioned power cycles for the previously mentioned case study. Net power output of the cycles is the main parameter for comparison since it (when using a shaft motor) determines the resulting specific fuel consumption (SFC) and specific NOx emissions of the combined cycle. In addition, important qualitative implications are considered in the comparison of the three different power cycles.

Though the concept of the mentioned combined cycle processes has been well described in the open literature e.g. by MAN Diesel \& Turbo [2], modelling efforts for the design and optimisation are not. However, one well described example is Danov and Gupta [6,7], who presented a comprehensive mathematical model of a marine turbocharged diesel engine and a single pressure level steam Rankine WHR system including the associated auxiliary compo- 


\section{Nomenclature}

\section{Acronyms}

BOI Boiler

CAC Charge air cooler

CND Condenser

COM Compressor

ECO Economizer

EVA Evaporator

FWP Feed water pump

HP High pressure

HPP High pressure pump

IHX Internal heat exchanger

JWC Jacket water cooler

LP Low pressure

NOx Nitrogen oxides
ORC Organic Rankine cycle

PTG Power turbine generator

REC Recuperator

SEP Separator

SFC Specific fuel consumption

SOx Sulphur oxides

SUP Superheater

TC Turbocharger

TCC Turbocharger compressor

TCT Turbocharger turbine

TEU Twenty foot equivalent units

TUR Turbine

WHR Waste heat recovery nents. Validation of the model was presented at varied engine loads and speeds and the resulting fuel consumption was analysed.

This paper presents the result from similar modelling efforts with a model of a combined energy system, consisting of a large marine two-stroke low speed diesel engine, a turbocharger and a WHR system. Compared to previous work, this study also includes the estimation of NOx emissions. This study further includes the comparison of three power cycles, a dual pressure steam cycle, a Kalina cycle and an ORC. In addition, the ORC optimisation method is more comprehensive, compared to previous work described in the literature, because it includes a combined optimisation of the process layout and the working fluid.

A description of the methodology is provided in section 2. Section 3 presents the results from the modelling efforts and section 4 discusses the results. Finally section 5 compiles the main findings.

\section{Methodology}

Although the main engine model was presented in earlier work of the authors [8], it is briefly outlined in the following for the purpose of consistency. Then, the methodologies used for modelling the WHR power cycles are briefly outlined as to the degree suitable for the present format. Finally in this section, the applied optimisation algorithm is briefly described.

All the WHR models have been made using Matlab 2010b in combination with the NIST Refprop fluid property database [9] to provide the thermo-physical properties for the exhaust gas and working fluids. The WHR system turbines were modelled using a polytropic efficiency, in order to be able to evaluate the cycles at a wide range of pressures and to ensure a comparable level of technology for the expanders. Heat exchangers were modelled using energy balances that were divided into a suitable number of equal parts, in terms of heat transferred, in order to check for and avoid pinch point violations. The pumps were modelled using isentropic efficiencies and not polytropic ones in order to reduce computational time. No pressure or heat losses were accounted for in order to simplify the approach. This can be allowed since the analysis is aiming at providing generic results only.

\subsection{Engine model}

Various engine model methodologies are described in the literature, ranging from full 3D fluid dynamic models to black box models. The model described in the following is a zero-dimensional model, a type which has been shown [10-13] to provide good predictions of engine performance while being fast enough for energy systems optimisation. Previous work of the authors [8] presented the model and the validation of it. The model was validated on the ability to predict the performance of a marine low speed twostroke engine in two different engine cases. Firstly, it was confirmed that the model could predict measured engine performance while being constrained by an extensive number of input parameters. Secondly, it was shown how the model responded to changes in engine tuning parameters with good accuracy. The validated parameters were those relevant for an electronically controlled engine, i.e. exhaust valve timing and variable injection timing. Also the effects of varying scavenging pressure were validated. 


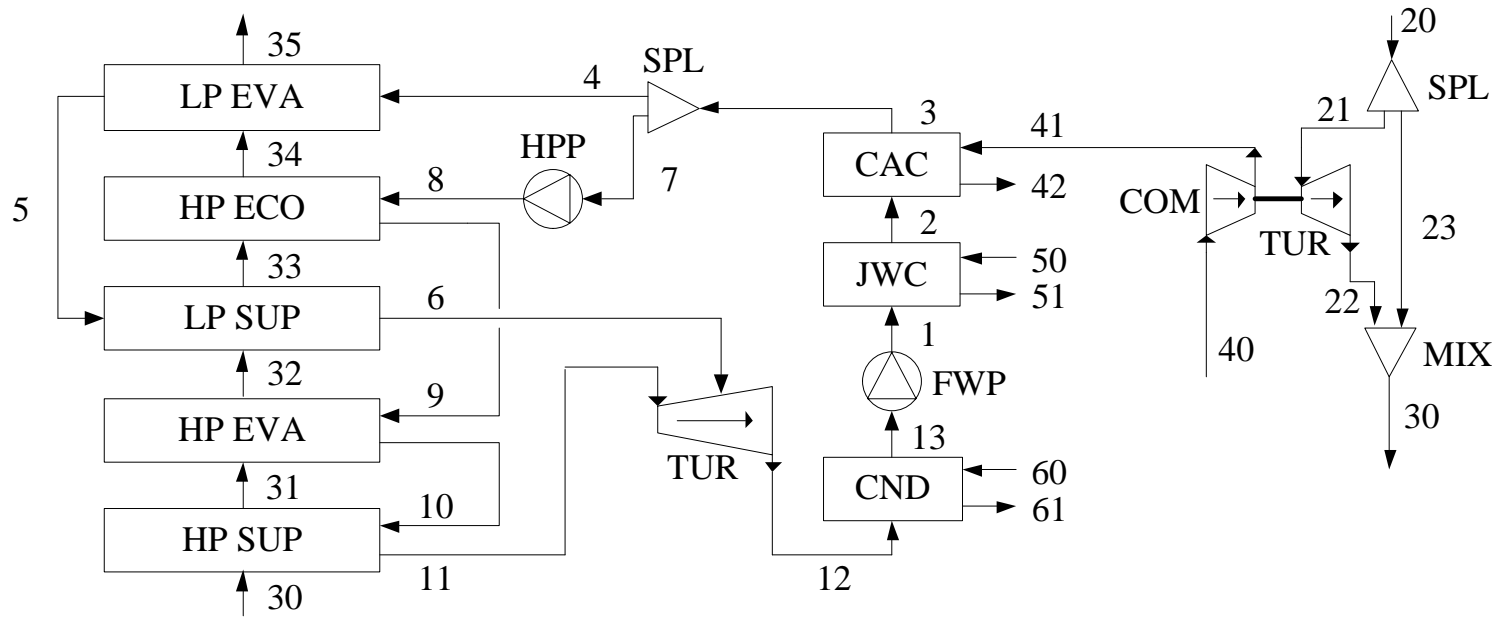

Figure 1: Steam Rankine process flow diagram

In the present study, the model estimates the brake power, waste heat flows, fuel consumption and NOx emissions of the main engine. The evaluation is mainly done by means of an energy balance and a two-zone combustion model which is integrated over a single engine cycle. The combustion process is divided into intervals, and the product composition and the flame temperature are calculated in each interval. A double Wiebe function [14] is used to estimate heat release. Heat losses in the cylinder are estimated using the Woschni correlation [15]. The NOx emissions are predicted using the extended Zeldovich mechanism [16].

The engine model utilises engine parameters from Goldsworthy [17] and the calibration was done as follows, to match measured performance data from the same source:

1. The end of injection timing was adjusted to obtain correct maximum cylinder pressure.

2. To obtain correct brake power output, the time of opening the exhaust valve was adjusted.

3. It was chosen to investigate a case of a mechanically controlled engine and therefore the best compromise for the exhaust valve opening time for both loads $75 \%$ and $100 \%$ was selected.

\subsection{Steam Rankine cycle}

Steam Rankine cycles are well described in the literature and proven in application. As inspiration for the steam Rankine cycle process layout in this study, was the plant currently proposed by MAN Diesel \& Turbo [2]. The process flow diagram is shown in Fig. 1.

Starting from (1) the working fluid (water) is at a low pressure. Running through an engine jacket water cooler heat exchanger (JWC) and then a charge air cooler heat exchanger (CAC), the water is preheated to the bubble point (3). The water stream is then split into two streams that run through a low pressure circuit (4) and a high pressure circuit (7) in the boiler. Hot exhaust gasses from the engine are running through the boiler from point (30) to (35). The low pressure stream is evaporated and superheated before entering the steam turbine (ST). The high pressure stream (7) is pumped to a high pressure, preheated, evaporated and superheated before entering the turbine. After the turbine (12), the stream is condensed.

The turbocharger (TC) is coupled to the process such that the exhaust gas from the engine is entering at (20) into a splitter which allows gas to be bypassed the TC turbine (TCT). The mass flow rate needed for the turbine to drive the compressor is lead through the turbine at (21) and the rest is bypassed and mixed with the cooler gas after the turbine. Charge air for the engine is compressed in the TC compressor (TCC) and is rejecting heat to the WHR process via the CAC at (40-42).

Validation of the steam cycle model was done using two different software, DNA [18] and the commercial tool Aspen Plus v. 7.2 [19]. The ability of DNA to model steam Rankine cycle power plants have been validated previously [20]. The results of the present model are the same as modelled results in DNA and Aspen Plus, see Table 6 in the Appendix.

\subsection{Kalina cycle}

The literature about the Kalina cycle is not comprehensive and the number of plants is modest at the present time, perhaps because the process was only invented in 1983 by Dr. Kalina [3] and because the technology is patented. The cycle is relatively complex and uses a mixture of ammonia and water as working fluid. Being a mixture, the working fluid evaporates and condenses nonisothermally and this potentially provide the advantage of a better match between non-isothermal heat sources and sinks [3]. The Kalina cycle has been proposed in many different configurations and in the present study, the model is made with a configuration similar to those found in work 


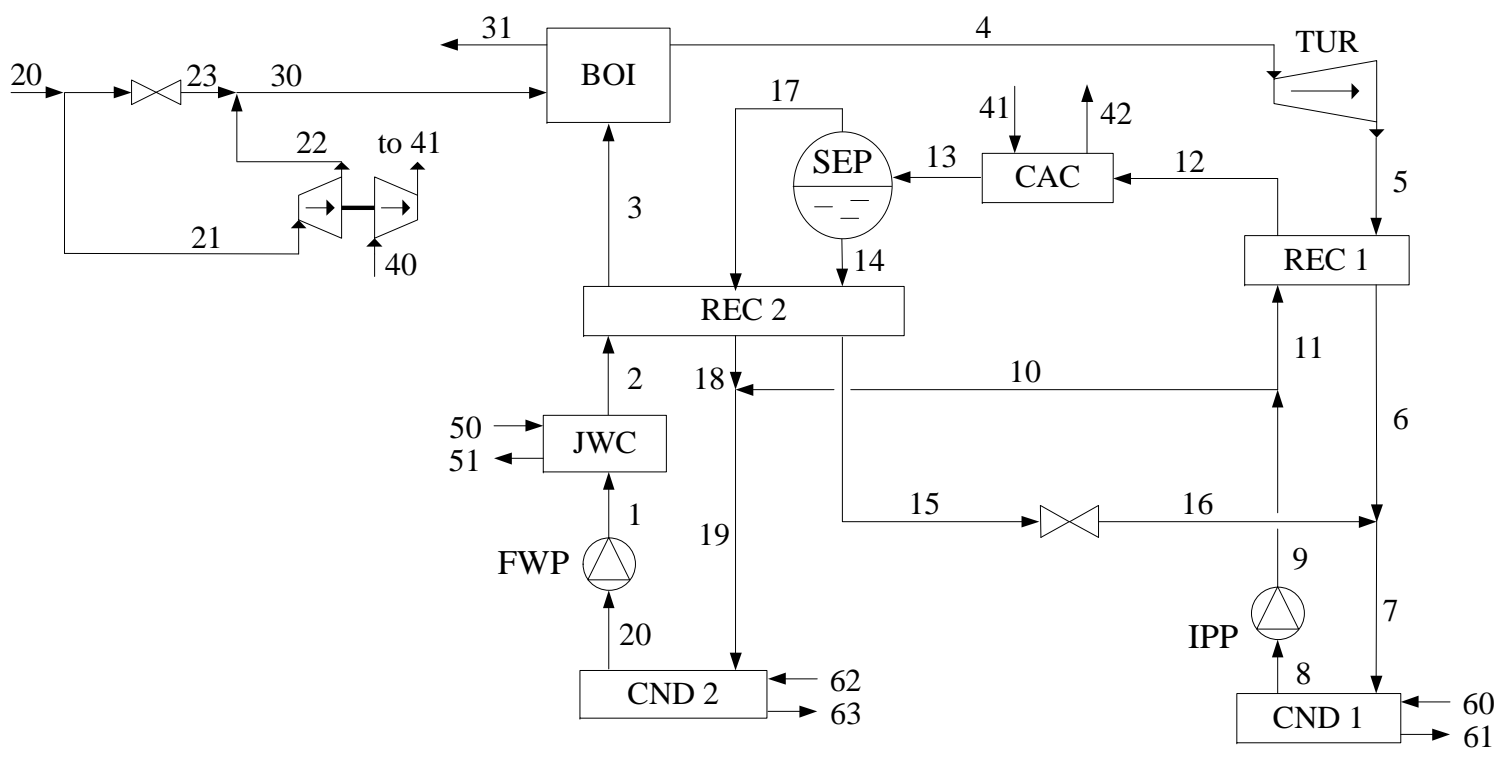

Figure 2: Kalina cycle process flow diagram

by Jonsson and Yan [21] and Bombarda et al. [5], which have been found suitable for marine application.

Figure 2 illustrates the process flow diagram of the Kalina cycle and the TC. Starting from the feed water pump (FWP), the working fluid (1) is preheated in the JWC and further in a recuperator heat exchanger (REC 2 ). It then enters the boiler (BOI) where the exhaust gas from the engine (30) rejects heat in order to preheat, evaporate and superheat the working fluid. Power is extracted from the fluid in the turbine (TUR) where after the fluid give off heat in the recuperator (REC 1). The stream (6) is then mixed with another stream (16) before it is condensed. After the condenser, the stream (8) is pumped to an intermediate pressure before it is split into two streams (10) and (11). Stream (11) is heated via REC 1 and heated again via the CAC. The stream (13) then enters a separator which separates the stream into an ammonia lean liquid stream (14) and an ammonia rich vapour stream (17). Both of these streams give off heat in REC 2. The rich stream (18) is then mixed with stream (10) before it is condensed again.

As described by Marston [22], a key component in the cycle is the separator. To obtain maximum power, the stream running through the turbine (4), needs to be as ammonia rich as possible and at the same time the outlet pressure needs to be as low as possible. However, high ammonia concentrations require relatively high condensation pressures. Therefore, the separator supplies a stream of fluid with a relatively low concentration of ammonia (14), which is mixed with the turbine outlet stream (6). The separator also has to supply an ammonia rich stream (17) to be mixed with the stream that has been condensed (10), at a sufficient rate in order to restore the stream concentration which again will be running through the turbine.

For the separator to be able to deliver these concentra- tions and flow rates, the main concern is to ensure that the separator feed temperature is high enough and the feed pressure is low enough. The feed pressure is dictated by the need for condensation and thus depends also on the working fluid concentration and cooling water temperature and flow in condenser 2 (CND 2). Most important is the feed temperature which normally depends on the recuperation of energy from the turbine outlet stream. However, at low turbine outlet pressures there might not be enough heat to recuperate; hence there is a motivation for inserting the heat source of the $\mathrm{CAC}$ at this point.

Alternatively the CAC could be placed to preheat/evaporate the feed stream in points (2) and (3). However, by placing the CAC to heat the separator feed stream and then having a second recuperator (REC 2), it may be possible to recover most of the CAC heat for the feed stream. Another alternative would be to place the CAC as a source for reheating of the fluid after the turbine. However, these options were not explored in the present study due to the scope of the work.

Validation of the Kalina cycle model was done using the commercial tool Aspen Plus v. 7.2 [19] and a study by Leibowitz and Zervos [23]. The modelled results showed agreement within $1 \%$ of the numbers presented by Leibowitz and Zervos [23] and the results of the present model are the same as when using Aspen Plus, see Table 7 in the Appendix.

\subsection{Organic Rankine cycle}

The application of ORC plants is relatively new but rapidly rising in popularity. The main reasons for this seems to be the very high conversion efficiencies combined with a relative process simplicity, low cost, scalability and versatility. A key to the above properties of the ORC is the use of alternative working fluids, and thus the selection 


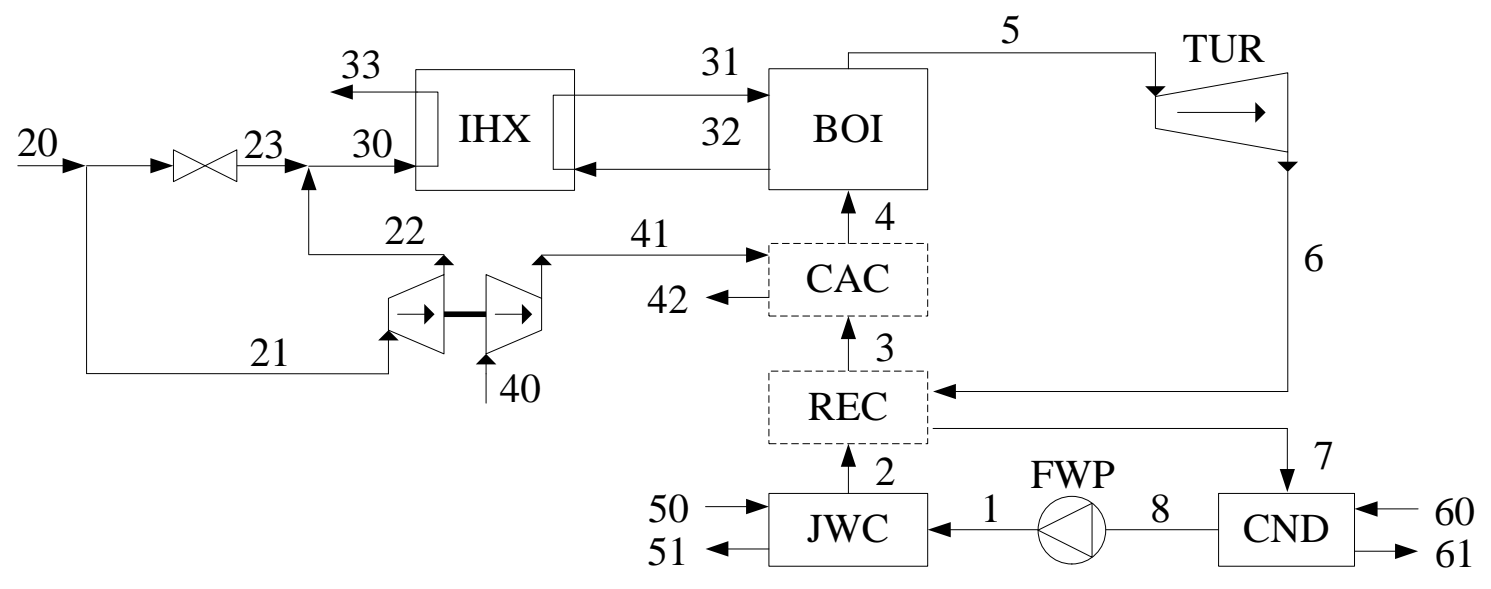

Figure 3: Organic Rankine cycle process flow diagram

of optimum working fluid has received a lot of attention in the literature. A recent example is the work of Wang et al. [24] who investigated a number of refrigerant fluids for engine waste heat recovery.

There seems to be a general consensus in that there may to be no single fluid which can meet the requirements of a safe and optimally efficient working fluid. Usage of organic fluids raises issues with fire hazard, ecological hazards, corrosiveness, lubrication properties and cost. Therefore, the selection of working fluid is about finding the best compromise of properties and it is in that sense difficult to objectively state the optimum choice.

Figure 3 illustrates the ORC process flow diagram. Working fluid enters the JWC at high pressure (1). Then it is heated further in a recuperator (REC) and in the $\mathrm{CAC}$ before entering the boiler. After the boiler, the fluid is expanded in a turbine before giving off heat in the recuperator (6). It is then condensed and pumped back to high pressure.

In the construction of the ORC process model used here, the optimisation algorithm was a strong factor. A total of 109 fluids from the Refprop fluid properties database have been tested using this model, and for that reason the model was made to adapt to the fluid characteristics. Most importantly in this regard is the fluid type; the wet type, which after expansion ends up as a mixture of liquid and gas such as water; the isentropic type, which has an isentropic saturation curve; and the dry type which after expansion is in a superheated state. A superheater is thus theoretically only needed for the wet type fluids.

Dry type fluids most often possess a great amount of heat after expansion and thus a recuperator is greatly beneficial to the overall cycle efficiency, whereas for wet and isentropic fluids, recuperation is most often not possible because the fluid is already at a saturated state.

Furthermore, due to the available heat from the jacket water and in many cases heat from recuperation, the heat available from the charge air may not be easily utilised. For these reasons an adaptable model was developed, such that the fluid properties, the different temperature levels and heat available could influence the process layout. The figure shows dashed lines around the CAC and the recuperator (REC) to illustrate that these components are optional for the process. Also the superheater is optional but in order not to prematurely discard any solutions of process and fluid, it was chosen to have the degree of superheating be an optimisation variable.

Many of the ORC working fluids are highly flammable and boiler leakages are therefore dangerous, risking explosions when highly flammable fluids come into contact with hot exhaust gasses. In order to avoid such a situation, an intermediate loop of heat transfer fluid (IHX) is transferring the heat to the boiler. A fluid designed for this purpose is a heat transfer fluid called DOW thermQ from the DOW chemical company and it was modelled as suggested by Pieronbon et al. [25].

Since the working fluids of the steam Rankine cycle and the Kalina cycle are non-flammable, this risk is not relevant and therefore no intermediate loop is used for the steam cycle and the Kalina.

Validation of the ORC model was done using the commercial tool Aspen Plus v. 7.2 [19] and the results of the present model are very similar as when using Aspen Plus for a range of tested working fluids, see Table 8 in the Appendix.

\subsection{Power turbine generator}

An alternative to the WHR systems described above is the power turbine generator (PTG), which is an exhaust gas powered gas turbine. The PTG is able to utilise the pressure component of the exhaust gas energy. The major part of the exhaust passes through the turbochargers, however, due to the excess turbocharger efficiency at high loads, some of the gas is bypassed the turbocharger and can be utilised by the PTG. The PTG is suggested as a cost-effective alternative for engine sizes similar to the presently studied [2]. It is in the present study assumed to have the same efficiency as the turbocharger turbine. 


\subsection{Optimisation}

Building on the principles of natural selection, the Genetic Algorithm [26] is an optimisation algorithm which optimises multiple parameters for any given model. The parameters to be optimised are emulated as genes of individuals which are part of a population. The fittest individuals are combined, as in nature, to form subsequent generations of individuals. The algorithm uses a stochastic approach to form the first generation of individuals. In the presented work, the genes were the parameters for the WHR system, i.e. the boiler pressure, and in the case of ORC and Kalina, the fluid and solution concentration, respectively. For the steam plant, the mass flow rate fraction in the high pressure circuit was optimised and for the ORC, the superheater approach was optimised. The turbine outlet pressure was optimised for the Kalina cycle only.

\subsection{Modelling parameters and conditions}

Table 1 lists the design and operation parameters used for the WHR process models. The exhaust gas temperature at the boiler exit was limited to $160^{\circ} \mathrm{C}$ for the prevention of sulphuric acid corrosion on heat exchanger surfaces. Since the TC compressor and the TC turbine operate at a limited pressure range and at the same conditions for all simulations, using an isentropic efficiency was assumed adequate. Efficiencies for the TC were calculated from the calibration case (see sec. 2.1.) at loads $75 \%$ and $100 \%$.

It is noted that the minimum boiler pinch point temperature difference is a minimum that is allowed to vary and assume higher values during optimisation.

Table 1: Design and operation parameters

\begin{tabular}{rr} 
Minimum superheater approach, ${ }^{\circ} \mathrm{C}$ & 20 \\
Exhaust gas temperature after boiler, ${ }^{\circ} \mathrm{C}$ & 160 \\
Minimum turbine steam quality, $\%$ & 85 \\
Minimum boiler pinch point temperature difference, ${ }^{\circ} \mathrm{C}$ & 10 \\
Condenser working fluid outlet temperature, ${ }^{\circ} \mathrm{C}$ & 40 \\
WHR turbine polytropic efficiency, $\%$ & 80 \\
Power turbine isentropic efficiency, \% & 89 \\
Pump isentropic efficiency, \% & 80 \\
TC compressor isentropic efficiency, \% & 84 \\
TC turbine isentropic efficiency, $\%$ & 89 \\
Charge air cooler pinch point temperature difference, ${ }^{\circ} \mathrm{C}$ & 10 \\
Jacket water cooler pinch point temperature difference, ${ }^{\circ} \mathrm{C}$ & 5 \\
Recuperator pinch point temperature difference, ${ }^{\circ} \mathrm{C}$ & 10 \\
\hline
\end{tabular}

\section{Results and analysis}

First in this section, results from the main engine calibration and tuning are presented. Following, the combined cycle performances are compared. Finally, a qualitative evaluation of other relevant aspects concerning each of the cycles is presented.

\subsection{Engine model}

Table 2 presents the calculated outputs from both the calibration efforts and the engine tuning (designated WHR engine). Calibration data is seen in the parentheses for 75 and $100 \%$ load cases, and these were obtained at ISO ambient reference conditions, i.e. $25^{\circ} \mathrm{C}$ and 1 bar pressure.

At $100 \%$ load, the model underestimates the power output, while it is overestimated at $75 \%$ load. Conversely, the SFC is overestimated at $100 \%$ load and underestimated at $75 \%$. The deviations are within $1 \%$ accuracy while NOx emissions are predicted with 5-10\% accuracy.

Except for the jacket water heat, the overall energy balance of the engine seems also to be predicted accurately. In the work of Goldsworthy [17], the source of the calibration values, it is not made clear whether lubrication oil heat from the engine is included in the stated amount of heat from the engine. Should that be the case, the calculated results are with an accuracy of $5-10 \%$ of the reference values.

An effort was made to tune the main engine such that exhaust gas temperature would be suitable for WHR at a design point of $85 \%$ MCR. As it was chosen to explore the case of a mechanically controlled engine and therefore the exhaust valve timing was constrained to the value of the standard case. However, the effects of changes in injection timing, scavenging pressure, fuel and air mass flow rates and cylinder wall temperature were investigated. A targeted increase of the exhaust gas temperature of $50-65^{\circ} \mathrm{C}$ was set as is in accordance with what is stated by MAN Diesel \& Turbo [2]. The exhaust gas temperature after the TC for the standard tuning $85 \%$ load is seen to be $179^{\circ} \mathrm{C}$ and WHR is assumed to be infeasible in this case. A combination of $10 \%$ lower charge pressure, $10 \%$ lower inlet air mass flow rate and an increase of $100^{\circ} \mathrm{C}$ of the averaged cylinder wall temperature, was found to be a fuel effective way to gain an increase of $55^{\circ} \mathrm{C}$. It is seen in Table 2 how this tuning also causes reduced jacket water heat and temperature of the charge air.

\subsection{Combined cycle}

A comparison of the calculated performance for the combined cycle is shown in Table 3 . The results suggest that the maximum obtainable net power production is highest for the ORC. The steam Rankine produces only about $75 \%$ of the power of the ORC and the Kalina process has a similar output. The power specific fuel consumption and NOx emissions are reduced accordingly.

The results indicate that by using the ORC WHR system, the SFC can be reduced by $5 \%$ while NOx increases slightly due to the generally higher in-cylinder temperature. The overall plant efficiency is $52.0 \%$ with the ORC compared to $49.4 \%$ without WHR. Table 3 also shows the potential output of a stand-alone power turbine generator. Being much less complex, the PTG produces a little more than half of the power produced by the Kalina cycle.

Table 4 presents the optimised parameters of each of the cycles. It is clear that the boiler pressure required to reach 
Table 2: Engine model outputs

\begin{tabular}{rrrrr}
\hline Performance characteristics & Standard & Standard & Standard & WHR engine \\
\hline Load, \% maximum continuous rating & 100 & 85 & 75 & 85 \\
Power, MW & $19.66(19.81)$ & 16.93 & $14.92(14.86)$ & 16.93 \\
SFC, g/ $\mathrm{kWh}$ & $175.3(174.0)$ & 170.6 & $170.4(171.1)$ & 173.3 \\
NOx, g/kWh & $14.5(13.6)$ & 15.8 & $16.3(17.6)$ & 17.3 \\
Maximum pressure, bar & $141.0(141.0)$ & 135.5 & $126.0(126.0)$ & 128.3 \\
Exhaust temperature before TC, ${ }^{\circ} \mathrm{C}$ & $344(333)$ & 302 & $281(284)$ & 344 \\
Exhaust temperature after TC, ${ }^{\circ} \mathrm{C}$ & 204 & 179 & 173 & 234 \\
Charge air temperature after TC, ${ }^{\circ} \mathrm{C}$ & 181 & 161 & 146 & 148 \\
Fuel mass flow, kg/s & - & 0.115 & - & 0.1165 \\
Exhaust mass flow, kg/s & 52.1 & 46.2 & 41.9 & 42.1 \\
Charge air mass flow, kg/s & 51.2 & 45.4 & 41.2 & 41.3 \\
Jacket water heat, MW & $2.28(3.00)$ & 2.24 & $2.18(2.40)$ & 2.16 \\
\hline
\end{tabular}

Table 3: Combined cycle performance

\begin{tabular}{rrrrrr}
\hline & Engine & Steam & ORC & Kalina & PTG \\
\hline WHR power production, MW & - & 0.863 & 1.16 & 0.825 & 0.453 \\
Total power production, MW & 16.94 & 17.8 & 18.1 & 17.76 & 17.39 \\
SFC, g/kWh & 170.6 & 164.9 & 162.2 & 165.3 & 168.8 \\
NOx, g/kWh & 15.8 & 16.6 & 16.2 & 16.7 & 16.8 \\
Combined efficiency, \% & 49.4 & 51.1 & 52.0 & 51.0 & 49.9 \\
\hline
\end{tabular}

optimum power output is relatively high for the Kalina cycle compared to the others and this may influence the overall cost and safety precautions of the plant negatively.

It is notable that even though the ORC process optimisation algorithm was allowed to search for optimum also in the supercritical state domain, the optimum was found with a fluid just below the supercritical pressure. The optimal process layout of the ORC using R245ca as working fluid is having almost no superheating and thus this heat exchanger is not needed. R245ca is a HFC refrigerant fluid also known as penta-fluro-propane.

Figure 4 illustrates the optimum boiler heat transfer characteristics for comparison. The working fluid temperatures entering the boiler are similar for steam and ORC processes while about $40^{\circ} \mathrm{C}$ lower for the Kalina process. This indicates that the Kalina cycle utilises the jacket water and charge air heat less efficiently. The ORC process uses the jacket water, recuperator and then charge air cooler heat to preheat the working fluid to $140^{\circ} \mathrm{C}$, just as high as the steam cycle. Note that for the ORC process the heat source is the heat transfer fluid (abbreviated DOW).

It was further investigated to use a non-flammable working fluid in the ORC and thus be able to simplify the process and remove the intermediate heat transfer circuit. The optimum net power obtainable for such a system was found to be $1060 \mathrm{~kW}$ and in the combined cycle $18.00 \mathrm{MW}$, with R236ea working fluid at the supercritical pressure of 68.3 bar. This is quite close to the optimum power of 18.10 MW found using R245ca in the ORC in table 4. R236ea has a global warming potential of 1200 (CO2-equivalent 100 years horizon) compared to 560 for the R245ca fluid [27], and thus represents an increase in environmental impact.

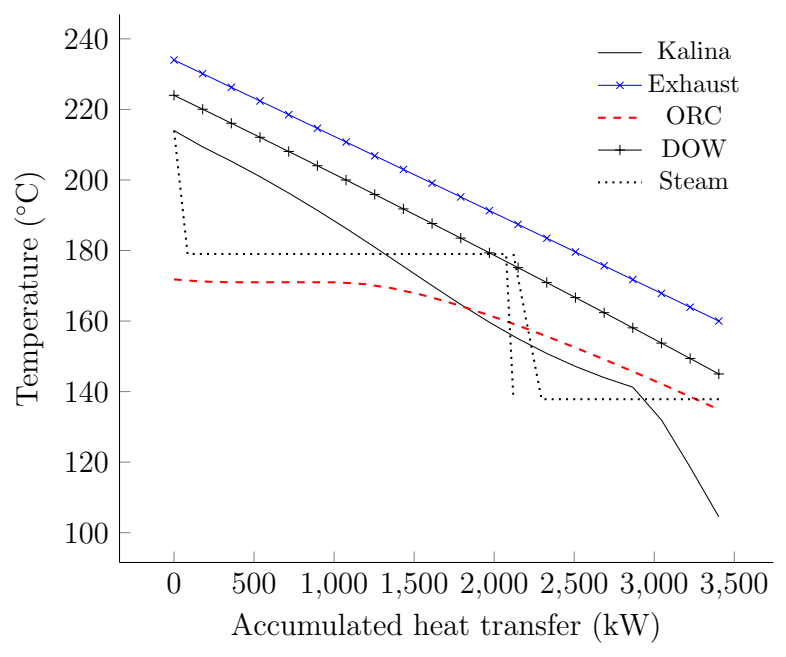

Figure 4: Boiler heat transfer diagram for the three power cycle alternatives

\subsection{Qualitative comparison}

Other aspects are drawn into the comparison of the three power cycles for a more complete analysis. In Table 5 each of the plant options are given a minus, zero or a plus to indicate a relative qualitative disadvantage, a neutral evaluation or an advantage, respectively.

Table 5: Comparative qualities

\begin{tabular}{lccc}
\hline & Steam & Kalina & ORC \\
\hline Net power output & 0 & - & + \\
Known technology & + & - & 0 \\
Process complexity & 0 & - & + \\
Toxic working fluid & + & - & - \\
Hazardous working fluid & + & 0 & - \\
Environmental concerns & + & 0 & - \\
Plant size & 0 & 0 & + \\
\hline
\end{tabular}

The plant size estimation is based on number of compo- 
Table 4: Combined cycle performance

\begin{tabular}{|c|c|c|c|c|c|}
\hline Steam & & ORC & & Kalina & \\
\hline Boiler pressure high, bar & 9.8 & Fluid & $\mathrm{R} 245 \mathrm{ca}$ & Boiler pressure, bar & 86.6 \\
\hline Boiler pressure low, bar & 3.4 & Boiler pressure, bar & 37 & Turbine outlet pressure, bar & 5.1 \\
\hline High pressure mass flow, $\%$ & 65.7 & Superheater approach, ${ }^{\circ} \mathrm{C}$ & 52.2 & Boiler ammonia concentration, $\% \mathrm{~m}$ & 76.4 \\
\hline
\end{tabular}

nents and working fluid density. A high density results in comparatively small equipment sizes [28] and R245ca has about 5 times higher density compared to both water and ammonia-water mixtures.

Each of the aspects may be weighted subjectively according to particular needs and requirements. It does seem, however, that the Kalina cycle cannot present any advantages in this context. The ORC presents advantages of being compact in size and the highly efficient with a relatively simple process layout. The steam cycle, being the industry standard, seems to be a desirable choice due to its high efficiency, proven technology and very good environmental profile.

\section{Discussion}

With the applied methodology it seems possible to quantify the performance improvement of utilising either of the three power cycles as WHR for marine applications. The accuracy of the results does however rely on the reliability of the thermodynamic equations of state, residing in the Refprop database. Refprop have been used for the modelling of various kinds of systems and has been validated throughout the literature, one example is Colonna [29]. Furthermore to the accuracy of the results; since the models in this study were made without any pressure and heat losses, the results should be interpreted as ideal, and thus smaller net power outputs can be realised in an actual plant.

While the investigations in this study were made for a single main engine load point, the decisions regarding WHR plant process layout and working fluid may rely on a range of load points. A combined optimisation of the main engine with TC and WHR versus a typical voyage load profile is therefore desired and subject for future work.

According to a MAN Diesel \& Turbo report [2], the steam WHR system may produce about $10 \%$ extra power where in the present study an increase of only $5 \%$ was found. The combined cycle efficiency in the report is stated to be $55 \%$ where in the present study $52 \%$ efficiency was achieved. The following reasons could be contributing to this discrepancy: Firstly, in the MAN Diesel \& Turbo report the WHR system includes both a Rankine cycle and a power turbine. Secondly, the fuel consumption in the present study was increased by $2.7 \mathrm{~g} / \mathrm{kWh}$ while in the mentioned report this number is $10 \mathrm{~g} / \mathrm{kWh}$. This indicates that the tuning involves a richer air fuel mixture in the main engine, compared to the tuning done in the present work. Consequently, the additional fuel input would increase the exhaust gas temperatures and mass flow rates and cause a significantly higher WHR system power output. In the previously mentioned report, the exhaust gas temperature entering the WHR system is $285^{\circ} \mathrm{C}$ compared to the $234^{\circ} \mathrm{C}$ shown in Table 2 . Lastly, a contribution may be that the WHR turbine efficiency of $80 \%$ used in the present work was assumed too low, and thus the respective power outputs may have been underestimated.

\section{Conclusion}

With the use of a previously derived marine two-stroke low speed diesel engine model, a simple turbocharger model and models of steam Rankine, Kalina and ORC WHR systems, the performance of the combined cycle was investigated. The engine model was tuned to produce a higher exhaust gas temperature for WHR system application. It was found that the tuning caused an increase in main engine fuel consumption, but the combined cycle fuel consumption was shown to be lower.

The results indicated that the ORC contributed with about $7 \%$ additional power and the Steam Rankine and Kalina cycles contributed with about $5 \%$ additional power. The application of a power turbine generator was found to be able to produce $2.5 \%$ additional power. In the best case, the specific fuel consumption was reduced from 170.6 to $162.2 \mathrm{~g} / \mathrm{kWh}$ with the ORC WHR system though with increased NOx emissions in exchange, due to the engine tuning.

When looking at other aspects than the mentioned, the Kalina cycle did not seem to offer any advantages. Instead, a number of drawbacks can be attributed, namely that the cycle is a relatively complex, unproven process utilising a toxic working fluid. The ORC plant offers the simplest plant layout with the highest efficiency. Drawbacks for the ORC are mainly related to the working fluid which is hazardous and environmentally damaging and perhaps it may also be a drawback that it is a relatively untested process in marine applications.

\section{Acknowledgements}

The authors wish to thank the Lighthouse Maritime Competence Centre, Gothenburg, Sweden, for the financial support making this study possible. Cecilia Gabrielii and Francesco Baldi of Chalmers University of Technology, Gothenburg, Sweden, are hereby thanked for proof reading and for giving valuable criticism to improve the work. 


\section{References}

[1] The International Maritime Organisation, IMO . IMO and the Environment. 2011. Acessed 2014-03-13; URL imo.org.

[2] Diesel and Turbo M. Waste Heat Recovery System (WHRS) for Reduction of Fuel Consumption, Emissions and EEDI. Tech. Rep.; MAN Diesel and Turbo; Copenhagen, Denmark; 2011.

[3] Kalina A. Combined cycle and waste heat recovery power systems based on a novel thermodynamic energy cycle utilizing low-temperature heat for power generation. Am Soc Mech Eng, (Pap); (United States) 1983;83-JPGC-GT.

[4] Marston CH, Hyre M. Gas turbine bottoming cycles: Triplepressure steam versus kalina. Transactions- American Society Of Mechanical Engineers Journal Of Engineering For Gas Turbines And Power 1995;117(1):10-.

[5] Bombarda P, Invernizzi CM, Pietra C. Heat recovery from Diesel engines: A thermodynamic comparison between Kalina and ORC cycles. Applied Thermal Engineering 2010;30(2-3):212 -9 .

[6] Danov SN, Gupta AK. Modeling the performance characteristics of diesel engine based combined-cycle power plants-part i: Mathematical model. Transactions- American Society Of Mechanical Engineers Journal Of Engineering For Gas Turbines And Power 2004;126(PART 1):28-34.

[7] Danov SN, Gupta AK. Modeling the performance characteristics of diesel engine based combined-cycle power plants - part ii: Results and applications. Journal of Engineering for Gas Turbines and Power 2004;126(1):35-9. doi:10.1115/1.1635397.

[8] Scappin F, Stefansson SH, Haglind F, Andreasen A, Larsen U. Validation of a zero-dimensional model for prediction of nox and engine performance for electronically controlled marine two-stroke diesel engines. Applied Thermal Engineering 2012;37(0):344 -52. doi:10.1016/j.applthermaleng.2011.11.047.

[9] Lemmon E, Huber M, McLinden M. National Institute of Standards and Technology, Maryland, United States, Standard Reference Database 23 Reference Fluid Thermodynamic and Transport Properties-REFPROP, Software version 9.0. 2010.

[10] Hountalas DT. Prediction of marine diesel engine performance under fault conditions. Applied Thermal Engineering 2000;20(PART 18):1753-84.

[11] Asay RJ, Tree DR, Svensson KI. An empirical, mixing-limited, zero-dimensional model for diesel combustion. SAE Technical Papers 2004;:doi:10.4271/2004-01-0924.

[12] Descieux D, Feldt M. One zone thermodynamic model simulation of an ignition compression engine. Applied Thermal Engineering 2007;27(8-9):1457-66. doi: 10.1016/j.applthermaleng.2006.10.002.

[13] Payri F, Olmeda P, Martin J, Garcia A. A complete 0d thermodynamic predictive model for direct injection diesel engines. Applied Energy -Barking Then Oxford- 2011;88(12):4632-41.

[14] Miyamoto N, Chikahisa T, Murayama T, Sawyer R. Description And Analysis Of Diesel Engine Rate Of Combustion And Performance Using Wiebe's Functions. Proceedings - Society of Automotive Engineers 1985;:77-88.

[15] Woschni G. A universally applicable equation for the instantaneous heat transfer coefficient in the internal combustion engine. SAE International 1967;doi:10.4271/670931.

[16] Hishinuma Y, Kikuta K, Chikahisa T. Study on predicting combustion and nox formation in diesel engines from scale model experiments. Nihon Kikai Gakkai Ronbunshu, B Hen/Transactions of the Japan Society of Mechanical Engineers, Part B 1999;65(629):369-75.

[17] Goldsworthy L. Reduced kinetics schemes for oxides of nitrogen emissions from a slow-speed marine diesel engine. Energy and Fuels 2003;17(2):450-6. doi:10.1021/ef020172c.

[18] Elmegaard B, Houbak N. DNA A General Energy System Simulation Tool. SIMS 2005 and Tapir Academic Press. ISBN 82-519-2093-0; 2005, p. 43-52.

[19] Aspen Tech Massachusetts, USA . Aspen Plus Software Version 7.2. 2010. Accessed 01/06/2013; URL www. aspentech.com.

[20] Elmegaard B. Simulation of Boiler Dynamics: Development, Evaluation and Application of a General Energy System Sim- ulation Tool. ET-PhD; Technical University of Denmark, Department of Energy Engineering; 1999. ISBN 9788774752226.

[21] Jonsson M, Yan J. Ammonia-water bottoming cycles: a comparison between gas engines and gas diesel engines as prime movers. Energy -Oxford- 2001;26(1):31-44.

[22] Marston CH. Parametric Analysis of the Kalina Cycle. Journal of Engineering for Gas Turbines and Power 1990;112(1):0423111-04231111. doi:10.1115/1.2906464.

[23] Leibowitz HM, Zervos N. Installation and Early Test Results of a 3 MW Kalina Cycle Demonstration Plant. SAE International 1992;1992-08-03.

[24] Wang EH, Zhang HG, Fan BY, Ouyang MG, Zhao Y, Mu QH. Study of working fluid selection of organic rankine cycle (orc) for engine waste heat recovery. Energy -Oxford- 2011;36(5):340618.

[25] Pierobon L, Kandepu R, Haglind F. Waste heat recovery for offshore applications; vol. 6. American Society of Mechanical Engineers. ISBN 9780791845226; 2012, p. 503-12. doi: 10.1115/IMECE2012-86254.

[26] Chipperfield A, Fleming PJ, Pohlheim H, Fonseca CM. Genetic Algorithm Toolbox for use with Matlab. Tech. Rep.; Department of Automatic Control and Systems Engineering, University of Sheffield, United Kingdom; Sheffield; 1994.

[27] Agency USEP. Global Warming Potentials of ODS Substitutes. 2014. Accessed 2014-03-13; URL epa.gov/ozone/geninfo/gwps.html.

[28] Papadopoulos AI, Stijepovic M, Linke P. On the systematic design and selection of optimal working fluids for organic rankine cycles. Applied Thermal Engineering 2010;30(6-7):760-9. doi:10.1016/j.applthermaleng.2009.12.006.

[29] Colonna , van Putten . Dynamic modeling of steam power cycles. Applied Thermal Engineering 2007;27(2-3):467-80. doi: 10.1016/j.applthermaleng.2006.06.011. 


\section{Appendix}

$T, P, h, x, \dot{m}$ and $y_{N H 3}$ are temperature, pressure, specific enthalpy, vapour quality, mass flow rate and ammonia concentration (by mass). 
Table 6: Steam model state points and process power

\begin{tabular}{|c|c|c|c|c|c|c|c|c|c|c|}
\hline & \multicolumn{5}{|c|}{ Matlab with Refprop } & \multicolumn{5}{|c|}{ Aspen Plus } \\
\hline & $T\left({ }^{\circ} \mathrm{C}\right)$ & $P($ Bar $)$ & $h(\mathrm{~kJ} / \mathrm{kg})$ & $x(-)$ & $\dot{m}(\mathrm{~kg} / \mathrm{s})$ & $T\left({ }^{\circ} \mathrm{C}\right)$ & $P($ Bar $)$ & $h(\mathrm{~kJ} / \mathrm{kg})$ & $x(-)$ & $\dot{m}(\mathrm{~kg} / \mathrm{s})$ \\
\hline 1 & 40.0 & 3.4 & 167.9 & - & 1.501 & 40.0 & 3.4 & 167.9 & - & 1.501 \\
\hline 2 & 80.0 & 3.4 & 335.2 & - & 1.501 & 80.0 & 3.4 & 335.2 & - & 1.501 \\
\hline 3 & 137.8 & 3.4 & 579.9 & 0.00 & 1.501 & 137.8 & 3.4 & 579.9 & 0.00 & 1.501 \\
\hline 4 & 137.8 & 3.4 & 579.9 & 0.00 & 0.515 & 137.8 & 3.4 & 579.9 & 0.00 & 0.515 \\
\hline 5 & 137.8 & 3.4 & 2730.6 & 1.00 & 0.515 & 138.2 & 3.4 & 2731.4 & 1.00 & 0.515 \\
\hline 6 & 179.0 & 3.4 & 2820.1 & - & 0.515 & 179.4 & 3.4 & 2820.9 & - & 0.515 \\
\hline 7 & 137.8 & 3.4 & 579.9 & 0.00 & 0.986 & 137.8 & 3.4 & 579.9 & 0.00 & 0.986 \\
\hline 8 & 137.8 & 9.8 & 580.3 & - & 0.986 & 137.9 & 9.8 & 580.7 & - & 0.986 \\
\hline 9 & 179.0 & 9.8 & 758.6 & 0.00 & 0.986 & 179.0 & 9.8 & 758.6 & 0.00 & 0.986 \\
\hline 10 & 179.0 & 9.8 & 2776.3 & 1.00 & 0.986 & 179.0 & 9.8 & 2776.3 & 1.00 & 0.986 \\
\hline 11 & 214.0 & 9.8 & 2862.6 & - & 0.986 & 214.0 & 9.8 & 2862.5 & - & 0.986 \\
\hline 12 & 40.0 & 0.074 & 2272.3 & 0.87 & 1.501 & 40.0 & 0.074 & 2239.6 & 0.87 & 1.501 \\
\hline 13 & 40.0 & 0.074 & 167.5 & 0.00 & 1.501 & 40.0 & 0.074 & 167.5 & 0.00 & 1.501 \\
\hline 30 & 234.0 & 1.2 & 690.4 & - & 42.1 & 234.0 & 1.2 & 690.4 & - & 42.1 \\
\hline 31 & 232.2 & 1.2 & 688.3 & - & 42.1 & 232.2 & 1.2 & 688.4 & - & 42.1 \\
\hline 32 & 189.0 & 1.2 & 641.1 & - & 42.1 & 189.0 & 1.2 & 651.1 & - & 42.1 \\
\hline 33 & 188.0 & 1.2 & 640.0 & - & 42.1 & 188.0 & 1.2 & 640.0 & - & 42.1 \\
\hline 34 & 184.2 & 1.2 & 635.8 & - & 42.1 & 184.2 & 1.2 & 635.8 & - & 42.1 \\
\hline 35 & 160.0 & 1.2 & 609.5 & - & 42.1 & 160.0 & 1.2 & 609.5 & - & 42.1 \\
\hline 41 & 148.0 & 2.9 & 548.6 & - & 41.3 & 148.0 & 2.9 & 548.6 & - & 41.3 \\
\hline 42 & 139.3 & 2.9 & 539.7 & - & 41.3 & 139.3 & 2.9 & 539.7 & - & 41.3 \\
\hline 50 & 85.0 & 3.0 & 356.2 & - & 52.8 & 85.0 & 3.0 & 356.2 & - & 52.8 \\
\hline 51 & 83.9 & 3.0 & 351.4 & - & 52.8 & 83.9 & 3.0 & 351.4 & - & 52.8 \\
\hline \multicolumn{3}{|c|}{ FWP power $(\mathrm{kW})$} & & & 0.629 & & & & & 0.629 \\
\hline \multicolumn{3}{|c|}{ HPP power $(\mathrm{kW})$} & & & 0.850 & & & & & 0.850 \\
\hline \multicolumn{3}{|c|}{$\mathrm{LP}$ turbine power $(\mathrm{kW})$} & & & 250 & & & & & 250 \\
\hline \multicolumn{3}{|c|}{ HP turbine power $(\mathrm{kW})$} & & & 614 & & & & & 614 \\
\hline \multicolumn{3}{|c|}{ Cycle net power $(\mathrm{kW})$} & & & 862 & & & & & 862 \\
\hline
\end{tabular}

Table 7: Kalina model state points and process power

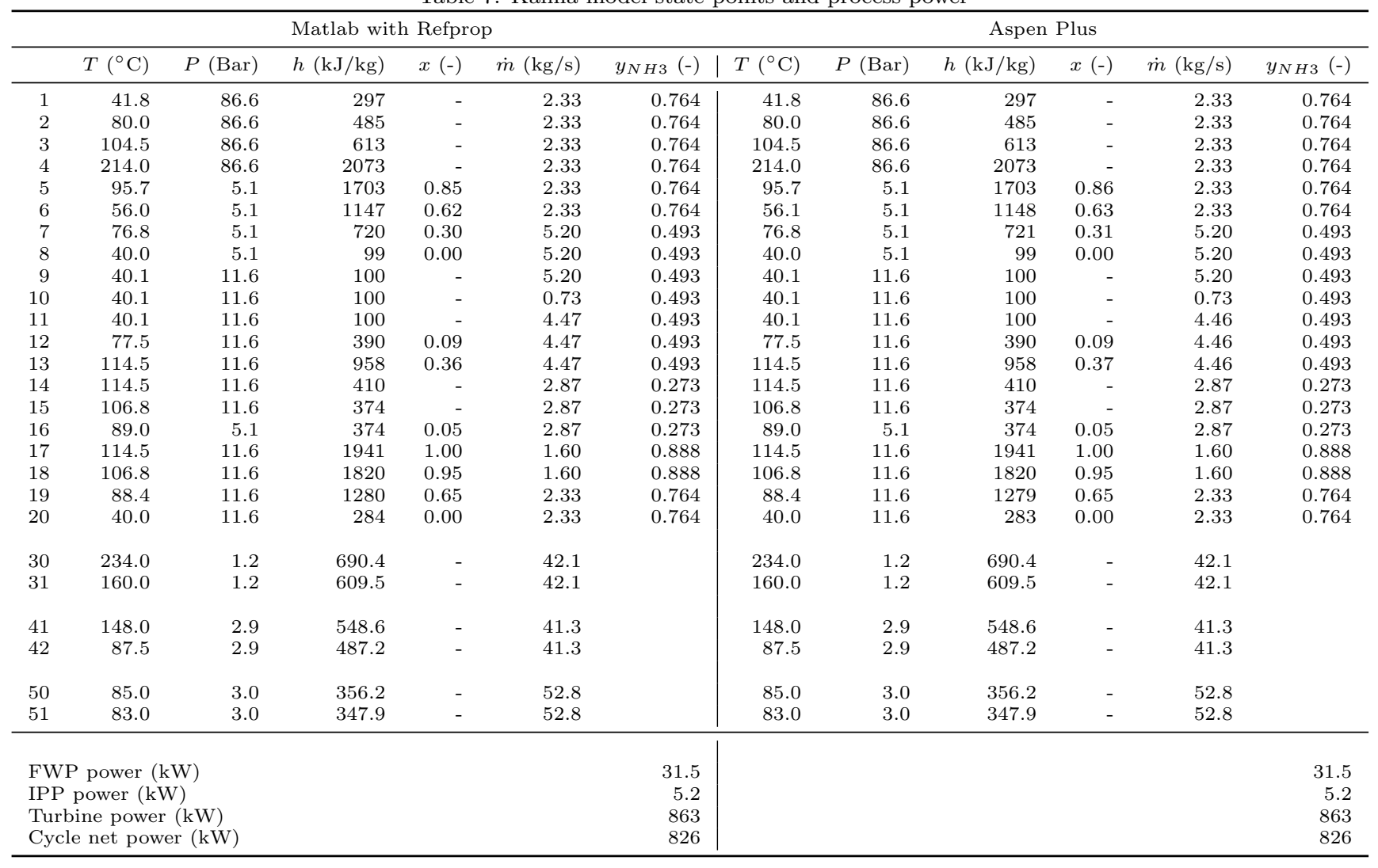


Table 8: ORC model state points and process power

\begin{tabular}{|c|c|c|c|c|c|c|c|c|c|c|}
\hline & \multicolumn{5}{|c|}{ Matlab with Refprop } & \multicolumn{5}{|c|}{ Aspen Plus } \\
\hline & $T\left({ }^{\circ} \mathrm{C}\right)$ & $P($ Bar $)$ & $h(\mathrm{~kJ} / \mathrm{kg})$ & $x(-)$ & $\dot{m}(\mathrm{~kg} / \mathrm{s})$ & $T\left({ }^{\circ} \mathrm{C}\right)$ & $P$ (Bar) & $h(\mathrm{~kJ} / \mathrm{kg})$ & $x(-)$ & $\dot{m}(\mathrm{~kg} / \mathrm{s})$ \\
\hline 1 & 41.6 & 37 & 258.2 & - & 28.3 & 41.6 & 37 & 258.0 & - & 28.3 \\
\hline 2 & 50.5 & 37 & 270.7 & - & 28.3 & 50.5 & 37 & 270.2 & - & 28.3 \\
\hline 3 & 57.1 & 37 & 274.8 & - & 28.3 & 57.1 & 37 & 279.4 & - & 28.3 \\
\hline 4 & 134.9 & 37 & 398.5 & - & 28.3 & 136.0 & 37 & 399.1 & - & 28.3 \\
\hline 5 & 170.8 & 37 & 518.9 & - & 28.3 & 172 & 37 & 518.1 & - & 28.3 \\
\hline 6 & 64.6 & 1.7 & 474.6 & - & 28.3 & 66.4 & 1.7 & 473.8 & - & 28.3 \\
\hline 7 & 60.5 & 1.7 & 470.5 & - & 28.3 & 57.3 & 1.7 & 464.6 & - & 28.3 \\
\hline 8 & 40.0 & 1.7 & 255.0 & 0.00 & 28.3 & 40 & 1.7 & 254.7 & 0.00 & 28.3 \\
\hline 31 & 224.0 & 1.2 & 431.3 & - & 20.1 & 224.0 & 1.2 & 431.0 & - & 20.1 \\
\hline 32 & 145.0 & 1.2 & 262.0 & - & 20.1 & 146.0 & 1.2 & 264.0 & - & 20.1 \\
\hline 41 & 148.0 & 2.9 & 548.6 & - & 41.3 & 148.0 & 2.9 & 548.6 & - & 41.3 \\
\hline 42 & 64.5 & 2.9 & 463.9 & - & 41.3 & 67.2 & 2.9 & 466.7 & - & 41.3 \\
\hline 50 & 85.0 & 3.0 & 356.2 & - & 52.8 & 85.0 & 3.0 & 356.2 & - & 52.8 \\
\hline 51 & 83.4 & 3.0 & 349.5 & - & 52.8 & 83.4 & 3.0 & 349.6 & - & 52.8 \\
\hline \multicolumn{3}{|c|}{ power $(\mathrm{k}$} & & & 92 & & & & & 92 \\
\hline \multicolumn{3}{|c|}{ Turbine power $(\mathrm{kW})$} & & & 1253 & & & & & 1253 \\
\hline \multicolumn{3}{|c|}{ Cycle net power (kW) } & & & 1161 & & & & & 1161 \\
\hline
\end{tabular}

